\title{
VATURE LIBRARY
}

RAVENS, CROWS, MAGPIES, AND JAYS

ONY ANGELL, 1978. University of Vashington Press, Seattle and Lonon. 112 pp. Cloth, \$14.95 U.S.

This large format $\left(8 \frac{3 / 4 "}{4} \times 11^{1 / 4 ")}\right.$ ook concerns itself with the birds of he family Corvidae found in North merica north of Mexico. The three rairie Provinces have 7 species of orvids (plus the hypothetical Pinon ay) found in a wide variety of abitats, from mountain heights to ie prairies and the coniferous rests of the north. They are the ost familiar of birds, yet few take e time to admire and study them. deed, the magpie and crow are iid to be the bane of the farmer's istence, and are persecuted, huntand poisoned. Decried as ricultural pests and nest robbers, ey are at the same time the most inlligent of birds and worthy in many spects of our admiration.

The book is divided into two main ctions, the first a "cast of charac's" introducing and describing 17 prth American species, plus the tive crow, or Alala, of the Hawaiian ands. It is perhaps here that the ok is weakest. Each species acunt comprises two pages, a full ge illustration by the author-artist fing a page of text. It is the text at I would criticize. More space uld have been devoted to details of scription, range and migration, bitat, food, and nesting. To be e, these subjects are all touched but in many cases there is only $f$ a page of text, and in some ac- counts half or more of this is devoted to personal or historical anecdotes of questionable value. Admittedly this is in keeping with the over-all feel of the book, but the second section provides a more suitable place for this type of narrative. More basic information in the first section would have made the book more useful.

An example is the page on the Common Crow. Little is really said, and here I found one of the very few obvious errors. The author states that there are three races or subspecies, while both Bent and the A.O.U. Checklist list four. In his only departure from A.O.U. Checklist nomenclature, he lumps the Northwestern Crow with the Common Crow, and half of the account is devoted to this "race." Though the Northwestern Crow may ultimately be relegated to subspecific status, it has not yet been, and I would have liked to see each given a full page with meatier information.

It is in the second section that the book really shines, and becomes more than just a picture-book. Under six chapter headings, the author discusses the mythology, behaviour, ecology and adaptations of these birds in a style that is immensely readable and informative. The reader who has not studied this group will be surprised at the wealth of fascinating data, all supported by references to original sources. His curiosity piqued by a multitude of fascinating tid-bits he may pursue his interests further by consulting the bibliography of 184 titles.

The author lives in the state of Washington, and has studied corvids 


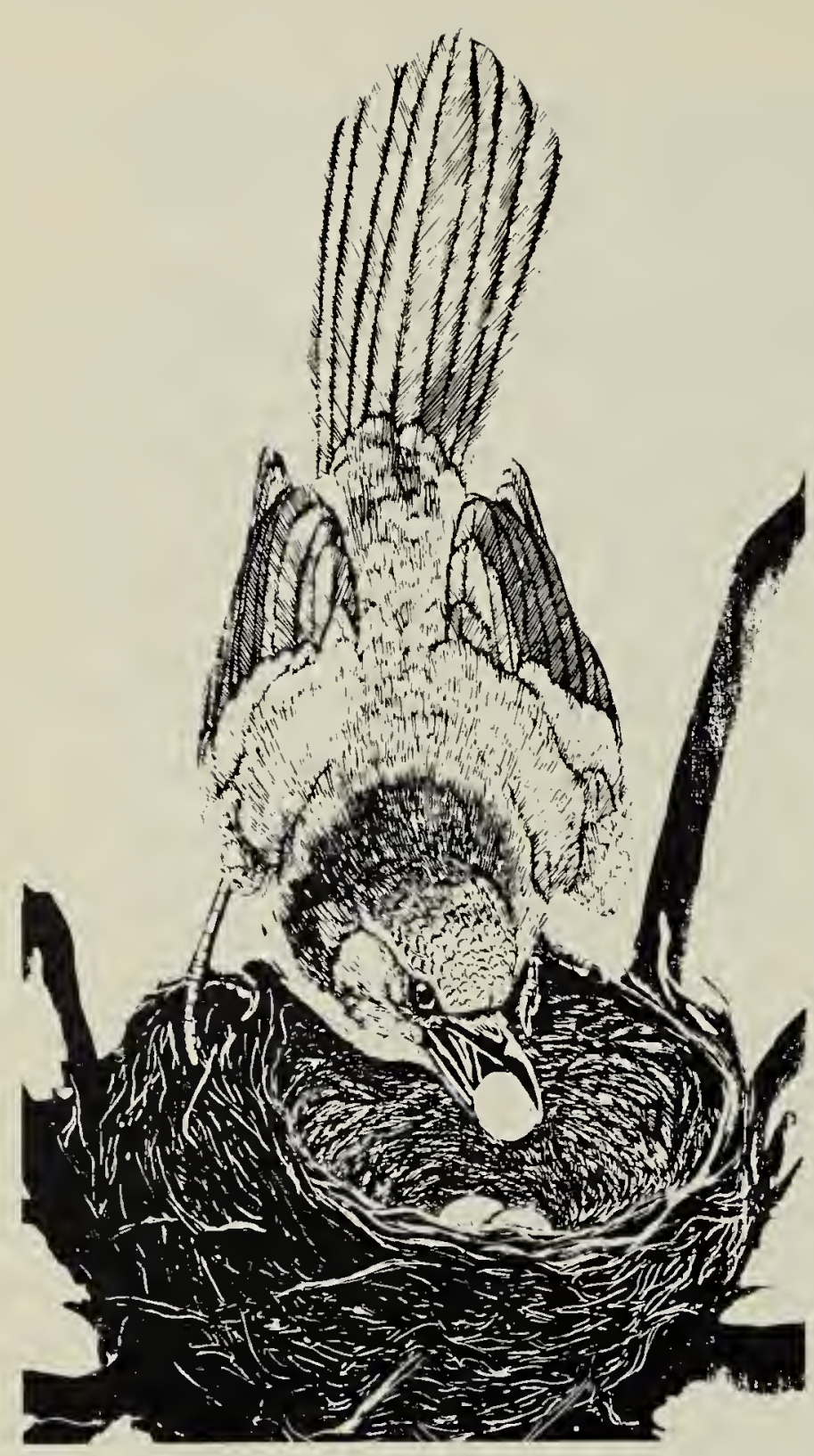

Scrub Jay, Illustration from the book

in many areas across the continent. His own experiences, especially in the Pacific Northwest, give this book a personal touch which, like the illustrations, illuminates the intelligence and personable nature of these birds. One is at once informed and entertained, and the book is hard to put down.

It is the art work that will first catch the reader's eye. At least every second page has an illustration, and many of them spill over on to the page facing. These black-and-white drawings portray their subjects in all the diversity of their activities and behaviour. What Angell has achieved here is a distillation of the essence of corvid life, and a joyous portrayal of the business of being a bird. Details are not always anatomically correct and at times the perspective is start ling (as in the "Raven chasing Goshawk") but these faults are easily overlooked in the artist's tota achievement.

The researcher looking for a mine of solid information on the North American Corvidae will have to look elsewhere, as in Derek Goodwin's Crows of the World (New York 1976). For the birder and naturalis curious about crows and their kin this is a superb introduction to the family, one certain to make the ob server more observant when he o she next encounters a member this diverse family. The first crow o spring will no longer be the only on to hold your interest after you reac this book. Highly recommended. Reviewed by Bob Kreba, Saskat chewan Museum of Natural History Regina, Saskatchewan.

\section{WILD COFFEE AND TEA SUBSTITUTES OF CANADA}

ADAM SZCZAWINSKI and NANC TURNER. 1978. National Museums Canada, Ottawa, Ontario. $111 \mathrm{p}$ $\$ 6.95$.

This book is a good field guide native plants that can be steeped brewed for beverages. Each of species is described under th following headings - how recognize, where to find, warnings necessary cautions, and how to $u$ (sometimes with recipes). The bo also tells how these plants were us: in the past for beverage ar medicinal purposes.

The introduction sketches $t$ history of coffee and tea as well as 